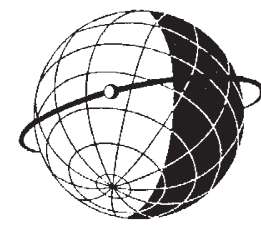

(1)

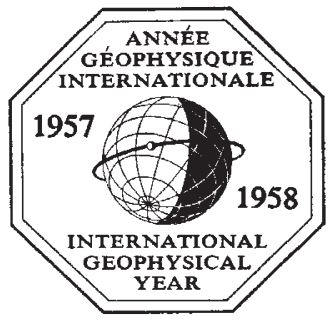

(2)
Symbol $\mathbf{l}$ is a representation of the Earth with meridians and circles of latitude, showing the south pole, to signify the special antarctic features of the International Geophysical Year ; part of the Earth is shown in darkness, implying the influence of the Sun ; a satellite orbit is shown encircling the Earth at an inclination to the equator, with the satellite, of course exaggerated in size, shown partly sunlit. Symbol 1 is to be used without change on publications issued by the Comité Spécial de l'Année Géophysique Internationale (CSAGI) and other International Geophysical Year publications under rules issued by the General Secretary of the Comité Spécial. This symbol does not include an inscription because the relevant information will normally be printed on the title page and cover of each publication. Symbol 2 is to be used on instruments, equipment or uniforms of personnel associated with the International Geophysical Year national committees, where the French or English language is appropriate; other national committees will substitute a translation of the inscription in the relevant language. If commemorative postage stamps are to be issued by any nation, the inscription may be used with the central symbol but otherwise disposed and with a border other than the octagonal one.

\section{Man-power in the Royal Air Force}

IN submitting the Air Estimates to the House of Commons on March 5, the Secretary of State for Air, Mr. Nigel Birch, referred at some length to the problem of saving man-power. Apart from limited inquiries into specific aspects of the subject, in which the Royal Air Force has had the assistance of business men, trade union officials and others, imaginative and effective work is going on all the time in the Royal Air Force itself, which has, he claimed, pioneered the application of scientific methods to the man-power question. This work has aimed not only at saving man-power but also at adjusting establishmonts in a highly technical and rapidly changing Service; further, the Air Ministry Man-power Research Unit has been in existence for many years and has done much good work. Inquiries are now being extended into the whole life and work of a station, and not only into specific aspects. For example, it has been found that in servicing opera. tional aircraft, with a slightly larger supervising staft and tradesmen with the corroct skills, considerablo savings in man-power can be effected. Arising out of the discovery of a desire to have the technical and administrative wings on the airfield brokon down into squadrons, experiments are being made with technical squadrons, signal squadrons, engineering squadrons, and so on, which have indicated that morale as well as efficiency are thereby improved. The application of these conclusions in a much bigger way on operational airfields is now being investigated by the Man-power Utilization Committee. Senior staff are also being sent to make special studies of work methods, not only in the Royal Air Force, but also in industry, and in this work they are having the help of young national service officers with honours degrees in scientific subjects, who were helping to work out the techniques.

Mr. Birch belìeves that the experience drawn from industry can have solid and substantial results in saving man-power and increasing efficiency, and that as a result of all these experiments it should be possible during the next two or three years to save some thousands of posts. He referred also to the need for very highly trained technical officers which is being mot by the Technical Cadot Scheme, and by the postgraduate training of serving officers, for example, in the postgraduate course in guided weapons. The real background of the Royal Air Force was, and will remain, however, the general duties officer, and the period of training at Cranwell has been extended to three years, first to enable the cadets to finish their training in jet aircraft, and second, to ensure that they have a good general education as well as a technical one.

Mr. G. S. de Freitas, while welcoming this reference to scientific research into man-power, and referring to the need for increasing the supply of scientists and technologists, as well as reducing unnecessary demands on the limited resources in Britain of skill and materials, suggested that more attention to buman relations in the Royal Air Force is also required. There was little other reference in the debate to what is already being done in the Royal Air Force to save man-power, although there was general recognition of the importance of deploying wisely scientific and technological man-power and increasing its supply so far as possible. Dr. A. D. D. Broughton, in supporting the idea of an exchange of technicians between the Service and industry, stressed the importance of keeping a careful watch on the competition for technical man-power between the Services and industry.

\section{Recent Earthquakes in Lebanon}

A SWARM of earthquake shocks, of which four were strong, occurred on the night of March 16 , and the following day. The epicentres were in the south of Lebanon, where considerable damage was done in some forty villages. Reports so far received state that 112 people are known to have been killed and more than a hundred injured. Considerable apprehension was caused, and thousands of people gathered on the shore, away from buildings. Minor earth tremors have been known to occur in Lebanon, but large shocks are infrequent there. The larger earthquakes are more frequent in southorn Turkoy.

\section{Preparation of Illustrations for Publication}

Illustrations in the form of drawings or graphs are often the most important feature of a scientific paper, and many research workers with little or no previous experience in the matter sometimes unwittingly cause considerable extra trouble and expense in editorial offices by submitting illustrations which require a great deal of alteration before they are suitable for reproduction. Most journals have their own peculiarities, and before submission of a paper intending authors should examine the particular journal they have in mind to see, for example, if any particular form and size of lettering is favoured (many journals prefer to set up letters and numbers in actual type when these occur outside the block). 